\title{
Coxsackie B4 viruses with the potential to damage Beta cells of the islets are present in clinical isolates
}

\author{
T.M.Szopa, T. Ward, D. M. Dronfield, N. D. Portwood and K. W. Taylor \\ Department of Biochemistry, The London Hospital Medical College, London, UK
}

\begin{abstract}
Summary. Infections with Coxsackie viruses (especially Coxsackie B4) are thought to be involved in the pathogenesis of diabetes. Many interdependent variables determine the outcome of an infection with a Coxsackie virus, one of them being the tropism of the virus for a specific tissue. The extent to which Beta cell tropic variants of Coxsackie B4 virus occur naturally was assessed. Human isolates of this virus were tested in an in vitro system in which elevated insulin release from infected islets incubated at a non-stimulatory ( $2 \mathrm{mmol} / \mathrm{l}$ ) glucose concentration appears to be related to viral attack. Using this technique, 8/24 isolates tested, im-
\end{abstract}

paired secretory function in mouse islets. Some strains of Coxsackie B4 virus, therefore, will directly infect mouse islets in vitro leading to changes in islet cell function. In conclusion, these findings confirm that variants of Coxsackie B4 virus with the potential to damage Beta cells occur quite frequently in the natural population. In certain circumstances the damage they inflict on Beta cells may cause destruction of these cells, or precipitate overt diabetes.

Key words: Beta cells, Coxsackie B4 virus, insulin release, islets.
Environmental agents such as viruses are sometimes important in the pathogenesis of insulin-dependent diabetes. Epidemiological [1] and serological [2] data suggest that Coxsackie virus infections, especially with Coxsackie B4 virus, are involved in the disease process and there have been a number of case reports of Coxsackie virus infections which appear to be directly linked to the onset of diabetes [3-6]. In addition, the metabolic functions of islets are impaired following infection with certain non-lytic strains of Coxsackie B4 virus both in vivo [7-9] and in vitro [10]. Many factors, both host and viral, influence the outcome of an infection. Importantly, the virus exists as a heterogeneous mixture of virions of different tropisms and pathogenicities $[11,12]$. It is also subject to a high rate of mutation [13] which may alter tropism and lead to a particularly severe attack on a specific organ.

Coxsackie $\mathrm{B} 4$ viruses are pathogenic in mice as well as humans and thus the murine model has proved to be of great value in studies of virus-induced diabetes. Earlier studies from other groups have shown that there are strains of Coxsackie B4 virus in the natural population which can induce glucose abnormalities in mice $[14,15]$. Our observation that in vitro some strains of virus induce a 'leakage' of insulin from mouse islets incubated at a nonstimulatory glucose concentration [10] prompted us to examine the possibility of using this relatively quick method to identify isolates which contain virions that might directly affect Beta cells. These strains do not necessarily cause Beta cell lysis $[8,9]$ but nevertheless cause Beta cell dysfunction.

\section{Materials and methods}

All chemicals, including bovine serum albumin, (Fraction $\mathrm{V}$ ) and collagenase (Type $1 \mathrm{~A}$ and Type $\mathrm{V}$ ) were of the highest grade, obtained from Sigma Chemical Co. (Poole, U.K.). Insulin antiserum and human insulin standards were supplied by Wellcome Diagnostics Ltd., (Beckenham, Kent, U. K.).

Random samples of human Coxsackie B4 isolates were obtained from Public Health Service Laboratories in England. The viruses had been isolated from patients of varying ages, ranging from 1 week to 21 years, presenting with various symptoms such as headaches, febrile fits, sore throats and meningitis. None of the samples came from a patient with diabetes. The origin of the isolates was the throat, faeces or cerebrospinal fluid. The viruses had been passaged a maximum of three times in Vero cell culture and upon receipt received one further passage through Vero cells before use in the in vitro assay. The resulting virus stocks (and virus preparations) were titred by plaque assay on Vero cell monolayers and stored in aliquots at $-20^{\circ} \mathrm{C}$.

Prototype Coxsackie B4 virus (JVB strain) was passaged through tissue culture eight times, and the stocks were prepared and titred as above to produce CB4-1-CB4-3. Plaque purification of CB4-1 and CB4-3 was carried out on Vero cell monolayers and virus 
Table 1. The effect of laboratory preparations of Coxsackie B4 virus and encephalomyocarditis virus on the basal rate of insulin release from mouse islets in vitro $48 \mathrm{~h}$ post-inoculation

\begin{tabular}{lcl}
\hline Virus & \% change & $p$ value \\
\hline $\begin{array}{l}\text { Encephalomyocarditis virus, } \\
\text { myocardial (EMC1) }\end{array}$ & +688 & $<0.001$ \\
$\begin{array}{l}\text { Encephalomyocarditis virus, } \\
\text { myocardial (EMC2) }\end{array}$ & +50 & $<0.05$ \\
$\begin{array}{l}\text { Encephalomyocarditis virus, } \\
\text { neurotropic (EMC3) }\end{array}$ & +2 & $\mathrm{NS}$ \\
$\begin{array}{l}\text { Cloned prototype Coxsackie } \\
\text { B4 virus }\end{array}$ & -19 & $\mathrm{NS}$ \\
$\begin{array}{l}\text { Coxsackie B4, tissue } \\
\text { culture-adapted (CB4-1) }\end{array}$ & +47 & $\mathrm{NS}$ \\
$\begin{array}{l}\text { Coxsackie B4, mouse } \\
\text { pancreas-adapted (CB4-2) } \\
\begin{array}{l}\text { Coxsackie B4, mouse } \\
\text { pancreas + B-cell-adapted (CB4-3) }\end{array}\end{array}$ & +80 & $<0.01$ \\
\hline
\end{tabular}

a $\%$ change calculated as $\%$ increase or decrease in rate of insulin release from infected islets compared to equivalent control islets $(5-10$ replicates per observation); ${ }^{b}$ diabetogenic in mice

yields from islets were assessed by plaque assay. Encephalomyocarditis virus ( $\mathrm{M}$ and $\mathrm{E}$ strains) was prepared and titred using a modification of previously described methods [16].

\section{Isolation of islets}

Islets were isolated from the pancreases of male DBA/2 mice, aged 10-12 weeks, by collagenase digestion [17] and maintained in tissue culture in RPMI 1640 medium (supplemented with $5 \mathrm{mmol} / 1 \mathrm{glu}-$ cose, $20 \mathrm{mmol} / 1$ Hepes, $10 \%$ heat-inactivated fetal calf serum, $100 \mathrm{U} / \mathrm{ml}$ penicillin and $0.1 \mathrm{mg} / \mathrm{ml}$ streptomycin sulphate) for 18 $24 \mathrm{~h}$ at $37^{\circ} \mathrm{C}$ in a $5 \% \mathrm{CO}_{2}$ in air atmosphere.

\section{Infection of islets}

Islets were washed with fresh RPMI 1640 (as above but without serum) and then inoculated with virus suspension at a multiplicity of infection of $1: 10$.

Dilutions of the viral suspension when required were made in serum-free RPMI 1640. Control islets were treated identically throughout except that cell or tissue extracts without virus were used for sham-inoculations. The virus was allowed to adsorb for $1 \mathrm{~h}$ at $37^{\circ} \mathrm{C}$, the islets were then washed twice with RPMI 1640 medium with $10 \%$ fetal calf serum and cultured in fresh medium for 24 or $48 \mathrm{~h}$ at $37^{\circ} \mathrm{C}$ in a $5 \% \mathrm{CO}_{2}: 95 \%$ air incubator.

\section{Incubation of islets}

After the culture period, the islets were washed in a bicarbonate buffer (as above) [18]. Groups of 5-10 islets per tube were preincubated in fresh buffer for $30 \mathrm{~min}$ at $37^{\circ} \mathrm{C}$. The islets were centrifuged at $500 \mathrm{rev} / \mathrm{min}$ for $5 \mathrm{~s}$ then incubated for $1 \mathrm{~h}$ at $37^{\circ} \mathrm{C}$ in $150 \mu \mathrm{l}$ buffer containing $2 \mathrm{mmol} / 1$ glucose in the case of infected islets, and 2 or $20 \mathrm{mmol} / \mathrm{l}$ glucose in the case of controls (to test islet function). The incubation buffer was collected to assay insulin release using a standard radioimmunoassay [19]. The mean rate of insulin release from control islets was $2.8 \pm 0.5 \mathrm{pg}$ islet ${ }^{-1} \cdot \mathrm{min}^{-1}(n=9)$ at $2 \mathrm{mmol} / \mathrm{lglu}-$ cose concentration rising to $15.4 \pm 3.9 \mathrm{pg}$ islet ${ }^{-1} \cdot \mathrm{min}^{-1}$ at $20 \mathrm{mmol} / 1$ glucose concentration $(n=9)$ in the series of incubations carried out after $48 \mathrm{~h}$ in culture. Samples were heat-treated for $5 \mathrm{~min}$ at $65^{\circ} \mathrm{C}$ to inactivate the virus. This treatment was shown to have no effect on subsequent radioimmunoassay.

\section{Statistical analysis}

Release of insulin from islets infected with virus, was compared to equivalent control islets and statistical significance of differences assessed using Student's $t$-test.

\section{Results}

Table 1 shows the effects of infection of mouse islets with three strains of encephalomyocarditis virus (a murine pathogen) and different laboratory preparations of Coxsackie B4 virus in the test system used in the present study. Two myocardial (diabetogenic) preparations [20] of encephalomyocarditis virus (EMC1 and EMC2) caused significantly higher amounts of insulin to be released from islets following infection compared to control islets. The neurotropic (non-diabetogenic) strain (EMC3) had no effect. These results validate this test system.

A cloned prototype Coxsackie B4 virus, derived from the prototype known to be non-diabetogenic in mice [21] also had no significant effect on insulin release. The prototype Coxsackie B4 virus which had been serially passaged through Vero cells (CB4-1) produced no effect on mouse islets. The same isolate, after serial passage through mouse pancreas (CB4-2), or through mouse pancreas and then mouse Beta cells (CB4-3), induced varying degrees of insulin 'leakage' at basal glucose concentration.

Table 2 shows the effects of 24 clinical isolates on insulin release from infected islets. Eight of the isolates produced a significant increase in the rate of insulin release compared to equivalent control islets, ranging from 42 $316 \%$. The remainder of the isolates produced both increases and decreases in insulin release but the values were not significantly different from controls. Four of the 24 viruses were isolated from the faeces, three were isolated from throat swabs and one was isolated from the cerebrospinal fluid. One of the isolates (Isolate 12, Table 2) induced a marked threefold increase in insulin release.

Beta cell tropic variants of CB4 virus infect and replicate in islets. Plaque purified preparations derived from CB4-1 and CB4-3 (Table 1) were used to infect islets at a high multiplicity of infection (1 virion: 1 Beta cell). The amount of virus released into the culture medium was assessed by plaque assay (see Methods) at various time points. At 24-h post-infection islets infected with CB4-1 derived virus yielded $<0.1 \%$ of the initial viral inoculum dose and islets infected with CB4-3 derived virus yielded $<0.3 \%$ of the initial viral inoculum dose. By 4.5 days postinfection there was a 9-fold and a 20 -fold increase in the amount of virus (compared to the inoculum dose) measured in the incubation medium in the two preparations respectively. Virus has also been found (by plaque assay) in both groups of islets from 24-h post-infection onwards following pretreatment with anti-CB 4 antibody to neutralise any extracellular virus and after lysis of the islet cells. 
Table 2. The effect of clinical isolates of Coxsackie B4 virus on basal insulin release from mouse islets in vitro $48 \mathrm{~h}$ post-inoculation

\begin{tabular}{|c|c|c|c|c|}
\hline \multicolumn{3}{|c|}{ Source of isolate } & \multirow{2}{*}{$\frac{\% \text { change }}{+30}$} & \multirow{2}{*}{$\frac{p \text { value }}{\text { NS }}$} \\
\hline Isolate CB4 & 1 & Faeces & & \\
\hline & 2 & Throat swab & -1 & NS \\
\hline & 3 & Cerebrospinal fluid & -12 & NS \\
\hline & 4 & $N / G$ & +92 & $<0.02$ \\
\hline & 5 & $\mathrm{~N} / \mathrm{G}$ & +33 & NS \\
\hline & 6 & $\mathrm{~N} / \mathrm{G}$ & +12 & NS \\
\hline & 7 & $\mathrm{~N} / \mathrm{G}$ & -30 & NS \\
\hline & 8 & $\mathrm{~N} / \mathrm{G}$ & -2 & NS \\
\hline & 9 & Faeces & +169 & $<0.01$ \\
\hline & 10 & Faeces & +42 & $<0.05$ \\
\hline & 11 & Throat swab & +33 & NS \\
\hline & 12 & $\mathrm{~N} / \mathrm{G}$ & +316 & $<0.001$ \\
\hline & 13 & $N / G$ & -37 & NS \\
\hline & 14 & $N / G$ & +39 & NS \\
\hline & 15 & $\mathrm{~N} / \mathrm{G}$ & 0 & NS \\
\hline & 16 & Throat swab & +43 & $<0.01$ \\
\hline & 17 & Throat swab & -23 & NS \\
\hline & 18 & Throat swab & -29 & NS \\
\hline & 19 & Throat swab & -23 & NS \\
\hline & 20 & Throat swab & -1 & NS \\
\hline & 21 & Faeces & +51 & $<0.05$ \\
\hline & 22 & Faeces & +40 & NS \\
\hline & 23 & Faeces & +43 & $<0.05$ \\
\hline & 24 & Throat swab & +89 & $<0.01$ \\
\hline
\end{tabular}

a $\%$ change as $\%$ increase or decrease in rate of insulin release from infected mouse islets compared to equivalent control islets (5-10 replicates per observation). $\mathrm{N} / \mathrm{G}$ not given

\section{Discussion}

In earlier work we have shown that some strains of virus damage the Beta cells of islets inducing excessive insulin release, even in the absence of cytolytic change [10]. In the present study it has been assumed that the increased release of insulin as an intracellular protein is an index of the capacity of the virus to attack Beta cells.

Two earlier studies investigating the diabetogenic potential of clinical isolates in vivo in mice have been recorded. Kuno et al. [14] examined the effects of 12 Coxsackie B4 clinical isolates on the blood glucose of mice and found that 7 of 12 produced hypoglycaemia within 2-4 days of inoculation, suggestive of Beta-cell damage and insulin 'leakage'. This has been observed with some of the preparations (CB4-2) used in this study [9]. In the second study Jordan et al. [15] estimated that 8 of 20 clinical isolates of Coxsackie B4 virus produced abnormalities in glucose metabolism in mice examined over a 17-day period. The study carried out demonstrates the existence of viral variants with the potential to impair islet cell function in the Coxsackie B4 virus pool, and suggests that they are quite common. These variants have direct effects on islets and could act as initiators of autoimmunity directed against the Beta cells or perhaps inflict damage which though not leading to overt diabetes could be important. Beta-cell dysfunction in which there is only limited damage to cells is known to occur quite frequently in man $[22$, 23]. In some individuals with a depleted Beta-cell reserve this type of attack could precipitate insulin insufficiency.

The cloned prototype Coxsackie B4 virus did not induce insulin 'leakage' from islets. Also, a preparation of virus which had been extensively passaged through tissue culture (CB4-1) did not have any significant effect on insulin release from mouse islets. Adaptation of the virus to mouse pancreas (CB4-2) or to mouse pancreas and Beta cells (CB4-3) increased tropism for the Beta cells and resulted in elevated insulin release in this system. These preparations (CB4-2 and -3 ) have been shown to impair insulin synthesis and release from mouse islets in vivo [9] and in vitro [10]. Previous workers have also shown that after passage of prototype Coxsackie viruses through Beta cells, transient hyperglycaemia can be induced in animals $[24,25]$.

The methods by which the virus causes 'leakage' without cytolysis is as yet undetermined, but virus-induced changes in permeability could be involved [26], or alternatively normal secretory mechanisms may be disrupted such that precursors of insulin (measured as 'insulin' in the RIA) are released.

In conclusion, these observations show that Beta-cell tropic variants are present in the general population of Coxsackie B4 viruses and suggest that in specific circumstances they could play some role in the pathogenesis of diabetes. The genome of the prototype Coxsackie B4 virus has been recently sequenced [27] and studies are now under way to compare the structure of Beta-cell tropic variants of the virus to the non-diabetogenic prototype, in order to identify molecular determinants of diabetogenicity.

Acknowledgements. This study was supported by the British Diabetic Association, the Wellcome Trust, and Action Research for the Crippled Child. We would like to thank Dr. D. R. Gamble for providing us with EMC virus and for valuable advice and discussion. We are also grateful to Professor J.W. Almond and Dr. O.Jenkins for the generous gift of a cloned prototype Coxsackie B4 virus, and to Mrs. R. Dobrin for preparation of the manuscript.

\section{References}

1. Gamble DR, Taylor KW (1969) Seasonal incidence of diabetes mellitus. Br Med J 3: 631-663

2. Gamble DR, Kinsley ML, Fitzgerald MG, Bolton R, Taylor KW (1969) Viral antibodies in diabetes mellitus. Br Med J 3: 627-630

3. Yoon JW, Austin M, Onodera T, Notkins AL (1979) Virus induced diabetes mellitus. Isolation of a virus from the pancreas of a child with diabetic ketoacidosis. N Engl J Med 300: 1173-1179

4. Champsaur H, Dussaix E, Samolyk D, Fabre M, Bach Ch, Assan R (1980) Diabetes and Coxsackie virus B5 infection. Lancet I: 251

5. Gladisch R, Hofmann W, Waldherr R (1976) Myokarditis und Insulitis nach Coxsackie-Virus-Infektion. Z Kardiol 65: 837-849

6. Nigro G, Pacella ME, Patane E, Midulla M (1986) Multisystem Coxsackievirus B6 infection with findings suggestive of diabetes mellitus. Eur J Ped 145: 557-559 
7. Chatterjee NK, Haley TM, Nejman C (1985) Functional alterations in pancreatic $\beta$ cells as a factor in virus-induced hyperclycemia. J Biol Chem 260: 12786-12791

8. Coleman TJ, Gamble DR, Taylor KW (1973) Diabetes in mice after Coxsackie B4 virus infection. Br Med J 3:25-27

9. Szopa TM, Dronfield DM, Ward T, Taylor KW (1989) In vivo infection of mice with Coxsackie B4 virus induces long-term functional changes in pancreatic islets with minimal alteration in blood glucose. Diab Med 6: 314-319

10. Szopa TM, Gamble DR, Taylor KW (1986) Coxsackie B4 virus induces short-term changes in the metabolic functions of mouse pancreatic islets in vitro. Cell Biochem Funct 4:181-187

11. Hartig PC, Madge GE, Webb SR (1983) Diversity within a human isolate of Coxsackie B4: relationship to viral-induced diabetes. J Med Virol 11:23-30

12. Gauntt CJ (1988) The possible role of virus variants in pathogenesis. In: Bendinelli M, Friedman $\mathrm{H}$ (eds) Coxsackieviruses. Plenum Press, New York, pp 159-173

13. Prabhakar BS, Haspel MV, McClintock PR and Notkins AL (1982) High frequency of antigenic variants among naturally occurring human Coxsackie B4 isolates identified by monoclonal antibodies. Nature 300:374-376

14. Kuno S, Itagaki A, Yamazaki I, Katsumoto T, Kurimura T (1984) Pathogenicity of newly isolated Coxsackievirus B4 for mouse pancreas. Acta Virol 28: $433-436$

15. Jordan GW, Bolton V, Schmidt N (1985) Diabetogenic potential of Coxsackie B viruses in nature. Arch Virol 86:213-221

16. Craighead JE (1966) Pathogenicity of the M and Evariants of the encephalomyocarditis (EMC) virus. I. Myocardiotropic and neurotropic properties. Am J Pathol 48: 333-345

17. Howell SL, Taylor KW (1968) Potassium ions and the secretion of insulin by islets of Langerhans incubated in vitro. Biochem $\mathrm{J}$ 108: $17-24$

18. Gey GO, Gey MK (1936) The maintenance of normal hormone cells and tumour cells in continuous culture. Am J Cancer 27: 4576

19. Hales CN, Randle PJ (1963) Immunoassay of insulin with insulin antibody precipitate. Biochem J 88: 137-146
20. Craighead JE, McLane MF (1968) Diabetes mellitus: induction in mice by encephalomyocarditis virus. Science 162: 913-914

21. Ross ME, Hayashi K, Notkins AL (1974) Virus-induced pancreatic disease: alteration in concentration of glucose and amylase in blood. J Infect Dis 129: 669-676

22. Johnston C, Raghu P, McCulloch DK, Beard JC, Ward WK, Klaff LJ, McKnight B, Bergman RN, Palmer JP (1987) $\beta$-cell function and insulin sensitivity in non-diabetic HLA-identical siblings of insulin-dependent diabetics. Diabetes 36: 829-837

23. Heaton DA, Millward BA, Gray IP, Yun T, Hales CN, Pyke DA, Leslie RDG (1987) Evidence for $\beta$-cell dysfunction which does not lead to diabetes: a study of identical twins of insulin-dependent diabetics. Br Med J 294: 145-146

24. Toniolo A, Onodera T, Jordan G, Yoon JW, Notkins AL (1981) Virus induced diabetes mellitus. Glucose abnormalities produced in mice by the six members of the Coxsackie B virus group. Diabetes 31: 496-499

25. Yoon JW, London WT, Curfman BL, Brown RL, Notkins AL (1986) Coxsackie Virus B4 produces transient diabetes in nonhuman primates. Diabetes 35: 712-716

26. Pasternak CA, Micklem KJ (1987) Virally induced alterations in cellular permeability: a basis of cellular and physiological damage. Bioscience Rep 1: 431-448

27. Jenkins O, Booth JD, Minor PD, Almond JW (1987) The complete nucleotide sequence of Coxsackievirus B4 and its comparison to other members of the picornaviridae. J Gen Virol 68: $1835-1848$

Received: 9 October 1989

and in revised form: 5 February 1990

\section{Dr. T.M. Szopa}

Biochemistry Department

London Hospital Medical College

Turner Street

London E1 2AD

UK 